\title{
The Impact of CALL Software on the Performance of EFL Students in the Saudi University Context
}

\author{
Ayman Khafaga ${ }^{1} *$ \\ Department of English, College of Science and Humanities, \\ Prince Sattam Bin Abdulaziz University, Saudi Arabia, \& \\ Department of English, Faculty of Arts and Humanities \\ Suez Canal University, Egypt
}

\author{
Abed Saif Ahmed Alghawli ${ }^{2}$ \\ Department of Computer Science, College of Science and \\ Humanities, Prince Sattam Bin Abdulaziz University, Aflaj \\ Kingdom of Saudi Arabia
}

\begin{abstract}
This paper investigates the extent to which Computer-Assisted Language Learning (CALL) contributes academically and pedagogically to the performance of students majoring English as a Foreign Language (EFL). The paper's main objective is to explore the extent to which CALL is effective in developing the linguistic and communicative competence of EFL students in the skill of reading. This paper uses both quantitative and qualitative approaches in the process of data collection. As an empirical study, the sample in this study was 47 students studying English at Prince Sattam bin Abdulaziz University. The participants were classified into two groups: experimental and control; each of which has been assigned specific reading activities. The experimental group has been allocated technological learning, by means of using the computer programs of Snagit ${ }^{\mathrm{TM}}$, Screencast; whereas the control group has been assigned traditional learning, i.e. without using computer. Results revealed that the use of CALL has more positive effects on the learning outcomes of the experimental group than those pertaining to the control group. This, in turn, accentuates the fact that the use and application of CALL into EFL contexts improves the students' learning outcomes concerning the skill of reading. The study recommends further integration of computer software into the designation of the different EFL courses.
\end{abstract}

Keywords-CALL; EFL students; Saudi university context; language skills; reading; Snagit ${ }^{T M}$; screencast; performance; effectiveness

\section{INTRODUCTION}

The overwhelming use and application of CALL (computer-assisted language learning) significantly influences the process of teaching and learning in all fields and disciplines in general, and in teaching and learning English as a foreign language (EFL) in particular. The employment of computer technologies in learning has caused unprecedented advancement beyond the limits of traditional and conventional sources of knowledge [1], [2]. The interest in digital technologies shapes all aspects of life; education is no exception. Educational technology dominates the process of learning and teaching EFL courses in the Saudi universities, specifically in recent years. This computer technology exceeds the boundaries of knowledge to the extent that contributes to the education of language skills and linguistic courses [3], [4].

As one innovative manifestation of technological advancement in learning, computer-assisted language learning (henceforth, CALL) is not intended to replace the traditional classroom instruction; however, its main concern is to enhance the performance of learners as well as to offer them further benefits on learning [5]. Students can easily use these computer software and applications in their learning regardless of time and place. They can use the different CALL programs to improve their linguistic competence and performance in the various language skills, including writing, reading, listening, speaking, vocabulary, etc. [6], as well as to practice their English language via specific interactive activities that can be followed by immediate feedback monitoring their linguistic progress [7].

CALL is a learning approach, whose theoretical, applied and pedagogical frameworks allow the use and application of computer programs and computer-based resources in teaching and learning English [8]. CALL is a technological system that can assist in not only the learning and teaching EFL courses, but also in improving the linguistic and communicative competence of EFL students [9]. According to [10], CALL is a computer program that is principally devised and developed to target educational purposes manifested in offering instructional help and support for both students and teachers in learning and teaching English. This program has been under a constant process of development since it has firstly been introduced to the field of learning and teaching EFL courses. Such a development has shifted the focus of this program from a simple digital program focusing on textbooks to very advanced digital programs that serve to grant students the opportunity of not only to learn English through the use of computer, but also to create and develop their own learning styles and outcomes. Crucially, the popularity CALL software has nowadays is due to the prominent impact of the information communication technology (ICT) that dominates both society and education [11], [12]. CALL provides both synchronously and asynchronously types of learning in a way that enables students to learn in a cooperative environment and to create communicative activities in pairs and in group [13].

In the Saudi educational system, CALL has relatively been a novel concept for many years because learning EFL is limited in practice and is confined to the classroom. Recently, CALL is introduced into EFL classes, particularly in Saudi universities. Nowadays, one can notice the application of CALL programs to almost all Saudi universities to the extent that some of these institutions have an independent course entitled CALL, as is the case for Prince Sattam bin Abdulaziz University, the setting where this study was conducted. This,

*Corresponding Author 
in turn, reflects the interest of applying and using computers in the educational process, and also demarcates a shift towards a technological education that covers all educational fields. Crucially, this fast digital shift is accompanied with an incessant process of training for instructors and students to ensure that they are up-to-date with the latest developments of technology. This paper, therefore, tries to explore the impact of using CALL software on the performance of EFL students in terms of learning the skill of reading at Prince Sattam bin Abdulaziz University. In so doing, this article can be perceived as an empirical study that targets to test EFL students' attitudinal behaviors towards the use of CALL programs and the way it influences their linguistic performance as well as their learning outcomes.

\section{A. Research Questions}

Based on the abovementioned introduction as well as the main purpose of the study, this article tries to answer the following overarching research question:

1) To what extent is the application of CALL software effective in learning the skill of reading in the Saudi university context? This research question constitutes a number of subsidiary questions that are further sought to be answered throughout this paper. These are as follows:

a) How does the use of CALL in the skill of reading activate autonomous learning and contribute to students' learning independence?

b) To what extent can learning outcomes of EFL students in the skill of reading be influenced via using CALL programs?

c) Does the use of CALL software in EFL courses increase students' learning motivation and curiosity?

\section{B. Research Objectives}

The answer of the aforementioned research questions comprises the main objectives of the current study:

1) To explore the extent to which the use of CALL software is effective in EFL classes within Saudi university context.

2) To shed light on the way learning outcomes concerning reading skill can be improved by the use and application of CALL software into EFL courses. This is accompanied with demonstrating the discrepancy in learning outcomes arrived at by the application of CALL software and those achieved by traditional instruction.

The remainder of this article is structured as follows: Section II presents the general theoretical background of the study, in which a brief account of the nature of CALL is provided; in this section some previous studies pertinent to the application of CALL software to EFL classes are also reviewed. Section III offers the methodology of the study, wherein data collection and description, research design and setting, participants, research instruments, and analytical procedures are provided. In Section IV, the results of the study elicited from the collected data are demonstrated. Section V is dedicated to discussing the results in relation to the findings of previous studies relevant to the contribution pertaining to the current paper. Section VI concludes the article and recommends further studies in the field.

\section{LITERATURE REVIEW}

\section{A. Computer-Assisted Language Learning (CALL)}

CALL, the result of the Information Age as well as the information communication technology, is a method of teaching and learning a foreign language [10]. Beatty [14] offers a definition for CALL, in which he states that it is a digital tool of teaching and learning English, wherein a computer is utilized in the process of education by a learner in order to improve his/her language. For [14], CALL is a tool whose dynamic functionality serves to facilitate the process of teaching and learning in a way that enables teachers to create innovative techniques in teaching the different language skills, including reading, writing, listening, speaking, vocabulary, etc.

According to [15], CALL motivates the online discourse environment on the part of both teachers and students. It helps learners present, develop and defend their ideas concerning specific topics. In today's EFL settings, CALL has become the feature of almost all linguistic programs applied to EFL courses [8]. Despite the fact that the use and/or application of CALL varies from one user to another, it is obvious that it fosters autonomy in the process of learning on the part of students [3]. This anticipated independent environment of learning, according to [16], is manifested in some procedures pertaining to self-directed learning that enables learners to set their personal perspectives in learning in a way that guarantees autonomous learning of some language skills outside the classrooms. As such, by employing CALL programs, students' performance can be evaluated in terms of the different skills of language they are supposed to learn. Significantly, selfdirected procedures in the process of learning serve to create pedagogical awareness on the part of learners and help them highlight their strengths as well as weaknesses during the process of learning [17].

Due to the rapid development in the computer technologies the whole world witnesses nowadays, using CALL software has occupied considerable significance in numerous studies, theoretically and empirically, that are concerned with learning and teaching EFL courses [18-22]. These studies shed light on the effective role of computers as digital tools assisting and facilitating a better educational environment, wherein learners feel motivated towards the realization of their educational goals, for example, [23] emphasizes that computers not only offer restrictive activities accompanied with simple graphics, but also provide further complicated activities that allow the integration of videos, sounds, animation and communication in today's world. This, in turn, functions to develop a better educational atmosphere that increases the motivational attitude of learners towards EFL learning.

In their attempts to assess the performance of students in terms of the application of CALL software to EFL classrooms, and the way this is activated by the learners' motivation, some researchers have clarified the reasons why computer technologies in general, and CALL software in particular play a significant and influential part in improving students' 
performance concerning the different skills of language [2429]. These studies list a number of reasons that revolve around the following ideas: (i) the availability of independent and autonomous learning; (ii) the proper accessibility to work with new digital tool of learning, which can replace the traditional tools of learning; (iii) the opportunity to have immediate services, such as reviewing and editing, as well as immediate feedback; (iv) the varieties in language learning activities, practices, and materials that are often missed in the traditional learning; and (v) computers can effectively foster learning of language skills in times and places where human performance in such skills proves to be inadequate.

According to [30], the educational and pedagogical advantages gained as a result of applying and using CALL software have been observed in the different skills of language, including the productive skills (writing and speaking), the receptive skills (reading and listening), and the other skills of language (vocabulary and grammar). Now, the question is: if various computer technologies contribute to the different skills of language, to what extent does the application of CALL software in the skill of reading influence the performance of learners in the Saudi EFL contexts? This is the core concern of this article.

\section{B. Previous Studies}

Much research has been conducted on the use and application of CALL software in learning and teaching English as a foreign language [31-39]. For example, Moras [40] investigated the effectiveness of using CALL programs and the Internet in EFL teaching in Brazil. Moras's study showed the interest of the English language teachers in the use of computers in teaching their courses to students. The study revealed that CALL programs have an influential role in directing the teaching and learning process from a teacherdependent towards student-independent process. This, in light of Moras's study, emphasizes the effective contribution CALL software provides for teaching and learning EFL courses.

The same results have been reported by [41], who also explored the extent to which CALL is effective in teaching and learning English in the American EFL context. This study supports the application of communication technology, including computers, the Internet and the educational software to the teaching and learning process, and concluded by confirming the contributive part CALL programs play in acquiring English as a foreign language. The same contributive effectiveness of the use of communication technology and CALL software in learning and teaching EFL courses in Georgia, USA was also reported by [42].

In another study, [43] addressed the Online Writing Labs (OWLs) as a featured function of CALL within EFL contexts. They proposed what they termed as 'product approach', which offers help for learners in the skill of writing. They maintained that this approach provides learners with certain resources to enhance their writing skill, by offering advices, including grammatical structures, vocabulary, text structures, reference style, cohesion, coherence, etc. For [3], the accessibility of the different CALL features and word-processing packages, such as hypertext, multimedia and hypermedia serve to help learners convey their ideas in the skill of writing.
Concerning the skill of reading, [44] argued that the use of CALL software allows non-linear reading via hypertexts, wherein learners can access other linked texts, highlight documents and construct their own interpretation and insights into the text under readership. They added that computer technologies in this case can provide learners with different reading aids that contribute to the general understanding of the reading texts and also increase the motivational attitude of students towards this skill. These technological tools constitute a variety of multimedia aids, including photographs, graphics, sound, animation, video, as well as other links to dictionaries and glossaries that serve to foster the process of learning the skill of reading and enhance students' performance [23].

In the Saudi EFL context, [45] investigated the possibility of integrating CALL in the education process by exploring the perceptions and attitudes towards using CALL in English among Saudi secondary EFL teachers. Alshumaimerie [45] used a sample from King Saud University constituting 183 participants to test their attitudes concerning the use of CALL into classroom instruction. The study revealed positive attitudes towards the integration of CALL as a digital tool in the teaching process, and clarified that the successful implementation of the information technology represented in CALL entirely depends on the attitudes of teachers and educators and contributes significantly to the whole process of teaching EFL courses.

In the same vein, Al-Mekhlafi [46] discussed the effectiveness of introducing CALL into EFL classes at preparatory schools. The study attempted to test the hypothesis of whether or not the use of computer increases the students' exposure to language, as well as the effect of this on the performance of students. The findings of Al-Mekhlafi's study showed that students who use computers in learning display better learning outcomes than those learn by traditional classes. The findings of this study accentuate the fact that the application and use of information technology, and more specifically CALL in EFL contexts is highly contributive to the process of learning and teaching.

\section{Methodology}

\section{A. Research Design and Setting}

This study is an empirical one conducted on students at the department of English, College of Science and Humanities, Prince Sattam bin Abdulaziz University, Saudi Arabia. The study constitutes two groups: experimental group and control group. Each group is assigned specific reading activities. The experimental group undergoes some reading activities technologically by the use of the two computer programs Snagit $^{\mathrm{TM}}$ and Screencast; whereas the control group is assigned the same reading tasks by means of a traditional method of learning, that is, without the use of any computer programs. The study was conducted in the second semester of the academic year 2020-2021 and lasted for eight weeks. Interestingly, the department of English at Prince Sattam University teaches a course entitled 'Computer-Assisted Language Learning', also abbreviated as CALL. This, therefore, facilitates the task of researchers in supervising and monitoring the study in its different stages, given the fact that 
the two researchers are affiliated and work at the same institution. The existence of CALL as an independent course in the department of English also helps in the management of the whole study for two reasons. First, the reading activities required for the analytical purposes are naturally incorporated into the delivered elements of the course; and, second, it guarantees the avoidance of any artificiality bias, either in the procedures adopted in the study or the data collection procedures.

\section{B. Participants}

The participants in the current study were 47 level-seven Saudi students who are studying English as a foreign language at Prince Sattam University. All participants were aged 19-21, and were studying CALL as an obligatory course in the department of English. Among the participants were 36 female students $(67 \%)$, while 11 participants were males $(23 \%)$. The participants were divided into two groups: an experimental group constituting 24 students and a control group including 23 students.

\section{Research Instruments}

Two research instruments were used in this study. The first was an interview, in which participants were directly asked about their experiences concerning the use of computers and CALL programs in their study of the different courses, the time they spend using computer every week, the availability of the computer sets, and the accessibility of the internet services during their study. The second research instrument was a questionnaire designed to test the participants attitudinal behaviors concerning using computer and computer programs in reading, the different activities they are assigned in this skill, and the way they perceive computer programs in the learning the skill of reading. The questionnaire consisted of 15 items with a 5-point Likert scale, including the response categories of: strongly agree, agree, no idea, disagree, and strongly disagree. The two instruments were employed to investigate the impact of using CALL on the performance of EFL students at Prince Sattam University.

Importantly, the study used version 11.1 on Windows of the program Snagit ${ }^{\mathrm{TM}}$. This computer program is run by TechSmith Corporation and serves to help users capture the elements they see on their computer screens. This includes capturing a text, a video, an image, etc. One option of Snagit $^{\mathrm{TM}}$ is called Snagit Editor, through which users can edit their captures and/or sharing them with any person and at any time. This option also helps users save their captures in various formats, including PDF, GIF, JPG, and EPS, insert them into different types of documents, including Word, PowerPoint or Excel, and share them through YouTube, Screencast, Facebook, Twitter and so forth. As for the Scrrencast, it is a computer program which enables users to record, save, and share any activities on their computer devices. This program also allows users to comment on each other's files and/or documents, which, in turn, serves to facilitate and support the process of interaction among users. The activities conducted via Screencast may include screen or webcam activities or both, and recorded activities may also be saved and shared as video file.

\section{Research Procedures}

The research procedures adopted in this study comprise two paralleled strands. The first is confined to the control group, whereas the second is dedicated to the experimental group. The procedural strands constitute three stages: pre-, in-, and post- process. The pre-process stage is a preparatory stage which offers general orientation to the two groups concerning the assigned reading tasks. The in-process is confined to the assigned reading tasks themselves pertaining to the two groups. This stage comprises three sub-stages: pre-reading, while-reading, and post-reading. The post-process is dedicated to the interpretation of results in terms of the assessment of participants' performance, either those who used CALL in conducting the required reading activities or those completed the activities traditionally, that is, without the use of computer programs. Importantly, when dealing with the experimental group, further specific procedures are applied. These include: (i) designing a questionnaire as well as an interview to provide the information concerning the experience of participants in dealing with computer programs in studying English as a foreign language; (ii) allowing the experimental group to conduct the activities by means of using the two computer programs of Snagit ${ }^{\mathrm{TM}}$ and Screencast, while the control group is only allowed to do the reading tasks assigned to the experimental group without using computers; and (iii) demonstrating the results elicited from the questionnaire and the interview after conducting the assigned tasks. After the completion of the three stages, a general interpretation of the results elicited from the research instruments used in the study is provided. In this stage, the obtained results are discussed in terms of the performance of the sampled participants. Results are also compared with previous studies approached the same topic. Significantly, the two groups were assigned the reading comprehension of one short story titled Enter Dragoon, written by Thomas Hardy in 1900. The assigned reading tasks are listed in Tables I and II.

TABLE I. ANALYTICAL PROCEDURES (CONTROL GROUP)

\begin{tabular}{|c|c|c|c|}
\hline \multicolumn{3}{|c|}{ Control group } & \multirow[b]{2}{*}{ Learning tools } \\
\hline Stage & Manifestations & Procedures & \\
\hline $\begin{array}{l}\text { Pre- } \\
\text { process }\end{array}$ & $\begin{array}{l}\text { Reading } \\
\text { orientation }\end{array}$ & $\begin{array}{l}\text {-Preparing the group } \\
\text { participants towards the } \\
\text { assigned tasks }\end{array}$ & \multirow{5}{*}{$\begin{array}{l}\text { Traditional } \\
\text { learning; no use } \\
\text { of computer } \\
\text { programs }\end{array}$} \\
\hline \multirow{3}{*}{$\begin{array}{l}\text { In- } \\
\text { process }\end{array}$} & $\begin{array}{l}\text { Pre-reading } \\
\text { activities }\end{array}$ & - Brainstorming & \\
\hline & $\begin{array}{l}\text { While-reading } \\
\text { activities }\end{array}$ & $\begin{array}{l}\text { - Identifying main } \\
\text { themes in the text } \\
\text { - Highlighting } \\
\text { ideological words in the } \\
\text { text } \\
\text { - Classifying the } \\
\text { characters in the text }\end{array}$ & \\
\hline & $\begin{array}{l}\text { Post-reading } \\
\text { activities }\end{array}$ & $\begin{array}{l}\text { - Answering some } \\
\text { comprehension } \\
\text { questions on the text }\end{array}$ & \\
\hline $\begin{array}{l}\text { Post- } \\
\text { process }\end{array}$ & $\begin{array}{l}\text { Results } \\
\text { interpretation }\end{array}$ & $\begin{array}{l}\text { - Assessing participants' } \\
\text { performance }\end{array}$ & \\
\hline
\end{tabular}


TABLE II. ANALYTICAL PROCEDURES (EXPERIMENTAL GROUP)

\begin{tabular}{|c|c|c|c|}
\hline \multicolumn{3}{|c|}{ Experimental group } & \multirow[b]{2}{*}{ Learning tools } \\
\hline Stage & Manifestations & Procedures & \\
\hline $\begin{array}{l}\text { Pre- } \\
\text { process }\end{array}$ & $\begin{array}{l}\text { Reading } \\
\text { orientation }\end{array}$ & $\begin{array}{l}\text {-Preparing the group } \\
\text { participants towards the } \\
\text { assigned tasks }\end{array}$ & \multirow{5}{*}{$\begin{array}{l}\text { Technological } \\
\text { learning; using } \\
\text { computer } \\
\text { programs of }^{\text {Snagit }}{ }^{\mathrm{TM}} \text { and } \\
\text { Screencast }\end{array}$} \\
\hline \multirow{3}{*}{$\begin{array}{l}\text { In- } \\
\text { process }\end{array}$} & $\begin{array}{l}\text { Pre-reading } \\
\text { activities }\end{array}$ & - Brainstorming & \\
\hline & $\begin{array}{l}\text { While-reading } \\
\text { activities }\end{array}$ & $\begin{array}{l}\text { - Identifying main themes } \\
\text { in the text } \\
\text { - Highlighting ideological } \\
\text { words in the text } \\
\text { - Classifying the } \\
\text { characters in the text }\end{array}$ & \\
\hline & $\begin{array}{l}\text { Post-reading } \\
\text { activities }\end{array}$ & $\begin{array}{l}\text { - Answering some } \\
\text { comprehension questions } \\
\text { on the text }\end{array}$ & \\
\hline $\begin{array}{l}\text { Post- } \\
\text { process }\end{array}$ & $\begin{array}{l}\text { Results } \\
\text { interpretation }\end{array}$ & $\begin{array}{l}\text { - Assessing participants' } \\
\text { performance }\end{array}$ & \\
\hline
\end{tabular}

\section{RESULTS}

This part demonstrates the results obtained from the questionnaire and the interview pertaining to the experimental group. The results pertinent to the control group were only used to compare those of the experimental group in the discussion section. This is because the core concern of the study is to monitor and explore the impact of using CALL on the performance of EFL students, which necessitates the analytical focus to be on the experimental group rather than on the control one.

\section{A. The Interview}

TABLE III. PARTICIPANTS' EXPERIENCE ON USING COMPUTER

\begin{tabular}{|c|c|c|c|c|c|c|c|}
\hline \multirow[t]{3}{*}{ Question } & \multicolumn{7}{|c|}{ Experience degree } \\
\hline & \multicolumn{2}{|c|}{ Low } & \multicolumn{2}{|c|}{ Moderate } & \multicolumn{2}{|c|}{ High } & \multirow[t]{2}{*}{ Total } \\
\hline & N. & $\%$ & N. & $\%$ & $\mathbf{N}$. & $\%$ & \\
\hline $\begin{array}{l}\text { To what extent do } \\
\text { you generally use } \\
\text { computer in } \\
\text { learning English as } \\
\text { a foreign } \\
\text { language? }\end{array}$ & 4 & 16.6 & 19 & 79.1 & 1 & 4.16 & 24 \\
\hline $\begin{array}{l}\text { To what extent are } \\
\text { you experienced in } \\
\text { Snagit }^{\mathrm{TM}} \text { and } \\
\text { Screencast? }\end{array}$ & 22 & 97.5 & 1 & 4.16 & 1 & 4.16 & 24 \\
\hline $\begin{array}{l}\text { Have you ever } \\
\text { practiced reading } \\
\text { comprehension by } \\
\text { using any } \\
\text { computer } \\
\text { technologies? }\end{array}$ & 15 & 62.5 & 7 & 29.1 & 2 & 8.32 & 24 \\
\hline
\end{tabular}

TABLE IV. PARTICIPANTS' RESPONSES CONCERNING TIME SPENT ON COMPUTER

\begin{tabular}{|l|l|l|l|l|l|l|l|}
\hline Question & \multicolumn{2}{|l|}{$\begin{array}{l}\text { Less than 5 } \\
\text { hours }\end{array}$} & \multicolumn{2}{|l|}{$\mathbf{5 - 8}$ hours } & \multicolumn{2}{l|}{$\begin{array}{l}\text { More than } \\
\text { 8 }\end{array}$} & Total \\
\hline $\begin{array}{l}\text { How many hours } \\
\text { have you spent in } \\
\text { learning by means } \\
\text { of computers per } \\
\text { week? }\end{array}$ & N. & $\%$ & N. & $\%$ & N. & $\%$ & \multirow{2}{*}{24} \\
\cline { 2 - 7 } & 13 & 54.1 & 7 & 29.1 & 4 & 16.6 & \\
\hline
\end{tabular}

As indicated from Tables III and IV, the majority of the participants in the experimental group expressed positive attitude concerning the extent to which they use computers in learning English as a foreign language. 19 (79.17\%) out of 24 participants have a moderate experience in terms of the use and/or applications of computer in the process of learning. This indicates that they are technologically familiarized to assign various reading activities by means of any technological tools. In question No. 2 which addresses the experience of the participants in the experimental group with regard to the use of the computer programs of Snagit ${ }^{\mathrm{TM}}$ and Screencast, a very high percentage of the participants display a negative attitude. Most of them (97.5\%) emphasized that they have a poor experience concerning the two programs used in this study. This indication in question No. 2 is accentuated by the participants' responses to question No. 3 , in which the majority of them $(62.5 \%)$ stated that their experience in terms of using computer technologies in reading is low, whereas $(29.16 \%)$ of them expressed a moderate degree in dealing with computer technologies when they read texts. The results obtained from Table III can be attributed, in one way or another, to the results displayed in Table IV, wherein experimental participants are asked about the number of hours they spend in learning by means of computer. In this regard, $(54.18 \%)$ of the participants stated that they spent less than 5 hours per week in learning via computer; (29.16\%) spent between 5 and 8 hours, whereas only (16.66\%) learn via computer for more than 8 hours per week. Here, the general indication is that the majority of the participants have positive attitude concerning the use of computer in learning in general; however, they have a negative attitude towards the application of specific computer programs into the process of learning in general and the skill of reading in particular. This further explains the rationale for selecting the skill of reading rather than the rest of other language skills to be the core concern of this study.

\section{B. The Questionnaire}

Table V shows the participants' response concerning their attitudinal perception of the use and application of CALL software in the skill of reading, and the effect of this on their linguistic competence and performance. 
TABLE V. PARTICIPANTS’ RESPONSE TO THE QUESTIONNAIRE

\begin{tabular}{|c|c|c|c|c|c|c|c|}
\hline No. & Statement & SA & $\mathbf{A}$ & $\begin{array}{l}\text { No } \\
\text { idea }\end{array}$ & D & SD & Mean \\
\hline & & \multicolumn{6}{|c|}{ Percent $\%$} \\
\hline 1 & I prefer to read texts via computer more than via textbooks. & 20.83 & 66.67 & 4.17 & 4.17 & 4.17 & 3.96 \\
\hline 2 & Reading via computer increases my learning curiosity. & 25.00 & 54.17 & 4.17 & 8.33 & 8.33 & 3.79 \\
\hline 3 & I think that using computer to practice reading is a waste of time. & 4.17 & 8.33 & 4.17 & 70.83 & 12.50 & 2.21 \\
\hline 4 & Using computers increases reading chances. & 16.67 & 62.50 & 12.50 & 4.17 & 4.17 & 3.83 \\
\hline 5 & Reading via computer saves time. & 29.17 & 58.33 & 4.17 & 4.17 & 4.17 & 4.04 \\
\hline 6 & Computers enhance my reading skills in a positive way. & 41.67 & 45.83 & .00 & 8.33 & 4.17 & 4.13 \\
\hline 7 & Computers offer immediate feedback on my reading. & 16.67 & 54.17 & 8.33 & 8.33 & 12.50 & 3.54 \\
\hline 8 & I understand texts well when I use computer in reading. & 20.83 & 66.67 & 4.17 & 8.33 & .00 & 4.00 \\
\hline 9 & Reading through computer develops my learning independence. & 29.17 & 58.33 & .00 & 8.33 & 4.17 & 4.00 \\
\hline 10 & $\begin{array}{l}\text { I can check the meaning of difficult words via online dictionaries when I read via } \\
\text { computer. }\end{array}$ & 25.00 & 54.17 & .00 & 8.33 & 12.50 & 3.71 \\
\hline 11 & Reading via computer hinders my comprehension of texts. & 4.17 & 20.83 & 4.17 & 54.17 & 16.67 & 2.42 \\
\hline 12 & I prefer visual and audible information when I read via computer. & 33.33 & 45.83 & .00 & 12.50 & 8.33 & 3.83 \\
\hline 13 & Using computer programs in reading facilitates the various reading activities. & 25.00 & 58.33 & .00 & 8.33 & 8.33 & 3.83 \\
\hline 14 & Using computer in reading increases my motivation towards learning. & 37.50 & 50.00 & 4.17 & 8.33 & .00 & 4.17 \\
\hline 15 & I prefer to continue using computer to learn the different language skills. & 33.33 & 54.17 & 4.17 & 4.17 & 4.17 & 4.08 \\
\hline
\end{tabular}

As displayed in Table $\mathrm{V}$, the questionnaire clarified one general fact: the attitudinal positivity in terms of the two response categories of strongly agree and agree. This, in turn, functions to emphasize the very positive attitude towards the use and application of computer and computer programs into learning the skill of reading. Responses in the above questionnaire indicate that a unanimous number of participants appeared to have high level of consent concerning using computer programs in reading. Through a simple observation of the questionnaire's items, one can identify five main points, all of which test the participants' attitudes in terms of the use of computer in reading. These are (i) preference of reading via computer and the intention to continue this in future (items 1,15); (ii) learning curiosity (items 2, 4); (iii) learning motivation (item 14); (iv) learning autonomy (item 9); and (v) improving reading skills (items 5, $6,7,8,10,12,13)$. These besides two negative items $(3,11)$, which were intentionally included in order to verify whether or not the participants read the questionnaire's items while completing it.

Concerning the preference to use computer in reading as well the intention to continue using it to learn the different skills of language in the future, a very high percentage (20.83\% for strong agreement and $66.67 \%$ for agreement) of the participants expressed their agreement that they prefer to practice reading by means of using computer. In terms of learning curiosity, the participants appeared to have a positive attitude (25\% and $54.17 \%$ for strong agreement and agreement options, respectively) that their learning curiosity is improved when they use computer to read any texts. This attitudinal positivity is subsequently accentuated by the participants' response regarding item 4 , wherein they stated that reading via computer serves to increase the chances of reading.

With respect to learning motivation, participants' responses also showed that they are highly motivated towards reading when they use computer $(37.50 \%$ and $50 \%$ for the response categories of strongly agree and agree, respectively). This is statistically reflected by the high mean of (4.17) for the questionnaire item No. 14. The same positive attitude has also been reported regarding learning autonomy, where (29.17\%) and $(58.3 \%)$ of the participants expressed their agreement in response to item No. 9. They emphasized that the use of computer in reading helps them feel autonomous. The learning independence can be ascribed to the freedom they have when they practice reading; there is not control from teachers, no feeling of shyness to commit mistakes, and, therefore, they feel that what they do is entirely their own work. They further stated that using computer in reading offers them immediate feedback on their reading.

As for the questionnaire items addressing the improvement of the skill of reading, they were responded positively by the participants. This has statistically been reported by the high mean these items have shown $(4.04,4.13,3.54,4.00,3.71$, 3.83 , and 3.83 for the items $5,6,7,8,10,12,13$, respectively). Participants expressed their agreement that using computer in reading saves their time and helps them comprehend the reading texts in an easy way. They also agree that through the use of computer they can browse both visual and audible information pertinent to the text they are assigned to read. 


\section{DISCUSSION}

The results showed that the use and application of CALL software positively influences the performance of EFL students at Prince Sattam bin Abdulaziz University. This effectiveness is clearly clarified from the responses of the experimental group to the interview and the questionnaire, as well as the observable discrepancies in performance between the control group and the experimental group in terms of the fulfillment of the reading tasks assigned to the two groups. It is analytically observed that the participants of the experimental group showed higher level of performance in conducting the assigned tasks than that of the control group. This performance discrepancy can be ascribed to the different technological aids participants in the experimental group had by means of using computer in reading the assigned novel. More specifically, and unlike the control group, the experimental group managed to identify the main themes in the novel, highlight the ideological words in the text, and classify the characters in the novel in an easy, accurate and fast way. They also managed to answer all the comprehension questions on the reading text. This is successfully arrived at because they were assigned to use the two computer programs, namely Snagit ${ }^{\mathrm{TM}}$ and Screencast, which added more effectiveness to students' performance in reading. The participants in the control group, on the other hand, did not manage to meet all the assigned reading tasks, either in quality or in quantity. That is, they spent much time in order to achieve the targeted tasks and fail to fulfill some of the activities, such as answering some of the comprehension questions listed on the novel. They also reflect low degree of performance when they were asked to recognize the ideological weight of some words from the text, or to classify some of the characters and themes in the novel.

The analysis also demonstrated that the impact of CALL on the performance of the students in the experimental group may be attributed to some factors. First, the employment of computer programs in reading have positively contributed to students' performance in terms of accessibility regardless of time and place, variability of presentation, speed, accuracy, flexibility of use and control, and information reciprocity among users. These elements are often missed if the process of reading is conducted traditionally, i.e. without the help of computer. Second, reading via computer makes students feel free from any pressures that may cause them to be shy or reluctant in doing the tasks assigned to them. They become information-seekers rather than information-receivers, as is the case with their counterparts in the control group. Third, the use of computer in reading develops the feeling of independence on the part of students in a way that makes them create their own education environment, as well as to feel autonomous and in complete control over the whole process of their learning. Fourth, the use of Snagit ${ }^{\mathrm{TM}}$ and Screencast enables students in the experimental group to capture texts, images, videos related to the reading text, and to edit files, save them in particular format, and sharing them with their groupmates in a fast and accurate way. Fifth, computers allow experimental students to get immediate feedback on what they read, either in terms of answering specific questions on the assigned reading text or in relation to correcting and verifying mistakes. The majority of these factors were missed with the control group, which, in turn, emphasizes the reason why computer has a great influence on the performance of EFL students. Significantly, the above findings correlate with many previous studies, such as [31-35], [47-49].These studies have acknowledged the positive impact of computer in learning English as a foreign language.

It is also evidenced from the results that the use of computer technologies in general and the two computer programs of Snagit ${ }^{\mathrm{TM}}$ and Screencast in particular serve to foster autonomous learning. These technological tools enable students to shape and reshape their educational contexts in a way that further serves to increase their curiosity and motivation towards learning. They also help them create an interactive type of communication, which influences their performance positively. This also goes in conformity with a number of previous studies, including [50-53] whose findings have emphasized the positively constructive impact of computers on the performance of EFL students.

A further interpretation pertinent to the impact of CALL software on the performance of EFL students concerning the skill of reading is the possibility of integrating visual and audible activities, such as those provided by Snagit ${ }^{\mathrm{TM}}$ and Screencast into the reading process. This is also anticipated to increase the learning motivation on the part of students and, thus, enhances their performance. This reconciles with [54] and [55], who highlighted the beneficial impact of the visual and audible sources on not only the skill of reading, but also on the other language skills, including writing, listening, speaking, and vocabulary. Crucially, the use, integration and application of CALL software in EFL classes have a very positive influence on the performance of Saudi EFL students, and greatly affect their learning outcomes.

\section{CONCLUSION}

This paper investigated the impact of CALL software represented by the programs of Snagit ${ }^{\mathrm{TM}}$ and Screencast on the performance of Saudi EFL students at Prince Sattam bin Abdulaziz University concerning the skill of reading. The study attempted to test the hypothesis that the use of CALL software contributes positively to the performance of EFL students, and enhances their learning outcomes. The analysis clarified that there are many differences between the two groups in terms of the activities and tasks allocated for each one. Unlike the control group, participants in the experimental group managed to meet nearly all the required reading tasks in a fast, accurate and interactive way, which accentuates the constructively positive influence computer has on learning the skill of reading. The analysis further demonstrated that the use of CALL software in EFL classes increases students' motivation and curiosity towards learning, and develops a feeling of independence that serves to foster autonomous learning.

Finally, this paper recommends further studies that may meet its limitation, by extending the analytical scope as well as the sample to cover other universities within the Saudi EFL context. These studies can explore the impact of CALL programs on the performance of EFL students concerning courses other than those dealing with the skills of language. For example, to assess and evaluate the performance of EFL 
students, who study drama, poetry, phonology, syntax, etc. These studies are anticipated to reveal findings different and/or similar to those approached in this paper or in any other studies whose core concern is language skills. Crucially, extending the research focus of using CALL in EFL contexts to include all EFL courses (i.e., not only language skills) might contribute to the fields of applied and computational linguistics.

\section{ACKNOWLEDGMENT}

The researchers would like to thank Prince Sattam bin Abdulaziz University in Saudi Arabia alongside its Scientific Research Deanship for all technical support it has provided to complete this study.

\section{REFERENCES}

[1] L. Pedro, C. Barbosa, and C. Santos, "A critical review of mobile learning integration in formal educational contexts," International Journal of Educational Technology in Higher Education, vol.15, no. 1, 2018.

[2] M. Eltahir, S. Al-Qatawneh, and S. Alsalhi, "E-Textbooks and their application levels, from the perspective of faculty members at Ajman University, U.A.E," International Journal of Emerging Technologies in Learning, vol. 14, no. 13, pp. 88-104, 2019.

[3] K. Beatty, Teaching and researching computer-assisted language learning. Harlow: Longman Pearson, 2010.

[4] D. M. Ahmadi, "The use of technology in English language learning: A literature review," International Journal of Research in English Education,vol. 3, no.2, pp. 115-125., 2018.

[5] C. A. Chapelle, Computer applications in second language acquisition: Foundations for teaching, testing and research. Cambridge, UK: Cambridge University Press, 2001.

[6] C. A. Chapelle, and J. Jamieson, Tips for teaching with CALL: Practical approaches to computer-assisted language learning. White Plains, NY: Pearson Education, 2008.

[7] R. S. Pinner, R. S., "Teachers' attitudes to and motivations for using CALL in and around the language classroom," Procedia - Social and Behavioral Sciences, vol. 34, pp. 188-192, 2012.

[8] G. Stockwell, Computer-assisted language learning: Diversity in research and practice. Cambridge: Cambridge University Press, 2018.

[9] E. Torlakovi and D. Deugo, "Application of CALL system in the acquisition of adverbs in English," Computer-assisted Language Learning, vol. 17, no. 2, pp. 203-235, 2004.

[10] C. Vrasidas, A. S. Georgeou, and E. Papanastasiou, "Educational media and innovative practice: Challenges and visions," Proceedings of September 2007conference on innovative learning environment. Nicosia, Cyprus: International Council for Educational Media, 2007.

[11] A. Zaytoon, Constructivism theory and its strategy in teaching science. Amman, Jordan: Al Shorroq Dar, 2007.

[12] A. Omar, A. F. Khafaga, and I. Shaalan, "The impact of translation software on improving the performance of translation majors," International Journal of Advanced Computer Science and Applications, vol. 11, no. 4, pp. 287-292, 2020.

[13] A. F. Abu Seileek, Cooperative vs. individual learning of oral skills in a CALL environment. Riyadh, Saudi Arabia: King Saud University, 2009.

[14] K. Beatty, Teaching and researching computer-assisted language learning. Harlow: Longman Pearson, 2010.

[15] L. Harasim, "Shift happens: Online education as a new paradigm in learning," The Internet and Higher Education, vol. 3, no. 1-2, pp. 41-61, 2000.

[16] J. Li, and A. Cumming, "Word processing and ESL writing: A longitudinal case study," International Journal of English Studies, vol. 1, no. 2, pp. 127-152, 2001.

[17] K. Hyland, Second language writing. Cambridge: Cambridge University Press, 2003.
[18] Y. H. Chen, "Computer mediated communication: The use of CMC to develop EFL learners' communicative competence," Asian EFL Journal, vol. 7, no. 1, pp. 167-182, 2005.

[19] H. Jarvis, and L. Pastuszka, "Electronic literacy reading skills and the challenges for English for academic purposes," CALL-EJ Online, vol. 10, no. 1, 2008.

[20] I. G. Singh, "The computer mediated communication to develop ESL learners' communicative competence," Journal of Literature, Culture \& Media Studies, vol. 2, no. 3, pp. 72-85, 2010.

[21] S. S. Terrell, "Integrating online tools to motivate young English language learners to practice English outside the classroom," International Journal of Computer-Assisted Language Learning and Teaching (IJCALLT), vol. 1, no. 2, pp. 16-24, 2011.

[22] A. Khafaga, "The perception of blackboard collaborate-based instruction by EFL majors/teachers amid COVID-19: A case study of Saudi universities," Journal of Language and Linguistic Studies, vol. 17, no. 2, pp. 1160-1173; 2021.

[23] K. Beatty, Teaching and researching computer assisted language learning. New York: Longman, 2003.

[24] L. Lee, "Learners' perspectives on networked collaborative interaction with native speakers of Spanish in the US," Language Learning and Technology, vol. 8, no. 1, pp. 83-100, 2004.

[25] H.J. Shin, and J. B. Son, "EFL teachers' perceptions and perspectives on Internet-assisted language teaching," CALL-EJ Online, vol. 8, no. 2, pp. 1-13, 2007.

[26] C. Y. Chiu, "The discourse of an English teacher in a cyber writing course: Roles and autonomy," The Asian EFL Journal, vol. 10, no. 1, pp. 79-110, 2008.

[27] A. Barger, and K. Byrd, "Motivation and computer-based instructional design," Journal of Cross-Disciplinary Perspectives in Education, vol. 4, no. 1, pp. 1-9, 2011.

[28] R. Dzekoe, "Computer-based multimodal composing activities, selfrevision, and L2 acquisition through writing," Language Learning \& Technology, vol. 21, no. 2, pp.73-95, 2017.

[29] A. Khafaga, and I. Shaalan, "Mobile learning perception in the context of COVID-19: An empirical studyof Saudi EFL majors," Asian EFL Journal, vol. 28, no. 1.3, pp.336-356, 2021.

[30] M. Sokolik, "Computers in language teaching," in M. Celce-Murcia (Ed.), Teaching English as a second or foreign language (3rd ed.), Boston, MA: Heinle \& Heinle, 2001, pp. 477-488.

[31] Q. Ma, "From monitoring users to controlling user actions: A new perspective on the user-centred approach to CALL," Computer Assisted Language Learning, vol. 20, no. 4, pp. 297-321, 2007.

[32] T. Chiu, H. Liou, Y. Yeh, "A study of webbased oral activities enhanced by automatic speech recognition for EFL college learning," Computer Assisted Language Learning, vol. 20, no. 3, pp. 209-233, 2007.

[33] A. AbuSeileek, "Cooperative vs. individual learning of oral skills in a CALL environment," Computer Assisted Language Learning, vol. 20, no. 5, pp. 493-514, 2007.

[34] A. Al-Menei, "An investigation of the effect of computerassisted writing instruction on EFL Saudi learners' ability," Unpublished Master Thesis, King Saud University, Riyadh, KSA, 2008.

[35] K. Romeo, "A web-based listening methodology for studying relative clause acquisition," Computer Assisted Language Learning, vol. 21, no. 1, pp. 51-66, 2008.

[36] I. A. Khan, "Diagnosis of learning difficulties in English: The Arabic bilingual context," Elixir Psychology,vol. 36, pp. 3448-3454, 2011.

[37] C. Z. Javid., U. Farooq, and M. Umer, "An investigation of Saudi EFL learners' writing problems: A case study along gender-lines," Kashmir Journal of Language Research,vol. 16, no. 1, pp. 179-203, 2013.

[38] A. M. Mudawy, "An attempt at promoting undergraduate sudanese EFL students' performance in academic writing skills," Arab World English Journal, vol. 10, no. 1, pp. 218-230., 2019.

[39] A. Khafaga, and M. Aldawsari, "Ideological agency in Edward Bond's Lear," Applied Linguistics Research Journal, vol. 5, no. 2, pp. 11-23, 2021. 
[40] S. Moras, "Computer-assisted language learning (CALL) and the internet," Karen's Linguistic Issues, 2001 Retrieved from http://www3.telus.net/linguisticsissues/CALL.html.

[41] A. Albarini, "Cultural perceptions: The missing element in the implementation of ICT in developing countries," Computers and Education, vol. 52, pp. 588-598, 2009.

[42] K. J. Cobb, "Facilitating second language acquisition through computerassisted language learning," Artmanuscript, vol. 1, no. 1, 2002.

[43] A. Walker, and G. White, Technology enhanced language learning: Connecting theory and practice. Oxford: Oxford University Press, 2013.

[44] R-C. Li, and R. S. Hart, "What can the world wide web offer ESL teachers?" In J. C. Richards, and W. A. Renandya (Eds.), Methodology in language teaching: An anthology of current practice, Cambridge, UK: Cambridge University Press, 2002, pp. 368-373.

[45] Y. Alshumaimeri, "Perceptions and attitudes towards using CALL in English among Saudi secondary EFL Teachers," The JALT CALL Journal, vol. 4, no. 2, pp. 29-46, 2008.

[46] A. G. Al-Mekhlafi, "The effect of computer-assisted language learning (CALL) on United Arab Emirates English as a foreign language school student's achievement and attitude," Journal of Active Learning Research, vol. 17, no. 2, pp. 121-142, 2006.

[47] C. A. Chapelle, and J. Jamieson, "Tips for teaching with CALL: Practical approaches to computer-assisted language learning. White Plains, NY: Pearson Education, 2008.
[48] A. AbuSeileek, "The effect of using a computer-based program on students' writing ability in English. Unpublished Doctoral Dissertation, Arab University, Amman, Jordan, 2004.

[49] A. Khafaga, and I. Shaalan, "Using concordance to decode the ideological weight of lexis in learning narrative literature: A computational approach," International Journal of Advanced Computer Science and Applications, vol. 11, no. 4, pp. 246-252, 2020.

[50] D. R. Ferris, Treatment of error in second language student writing. Ann Arbor; MI: University of Michigan Press, 2020.

[51] C. Pim, "Emerging technologies, emerging minds: Digital innovations within the primary sector," In G. Motteram (Ed.), Innovations in learning technologies for English language teaching, London: British Council, 2013, pp. 17-42.

[52] S-G. Wang, and C. Vásquez, "Web 2.0 and second language learning: What does the research tell us?" CALICO Journal, vol. 29, no. 3, pp. 412-430, 2012.

[53] A. Khafaga, and I. Shaalan, "Pronouns and modality as ideology carriers in George Orwell's Animal Farm: A computer-aided critical discourse analysis," TESOL International Journal, vol. 16, no. 4.2, pp. 78-102, 2021.

[54] A. Yeh, "Poetry from the heart," English Today, vol. 21, no. 1, pp. 45$51,2005$.

[55] A. Oskoz, and I. Elola, "Digital stories: Overview," CALICO Journal, vol. 32, no. 2, pp. 155-173, 2016. 